 \\ ENVIRONMENTAL

\section{Pollution Prevention Assessment for a Manufacturer of Locking Devices}

\author{
Richard J. Jendrucko*, Brian T. Hurst*, \\ and Gwen P. Looby
}

\section{Abstract}

The U.S. Environmental Protection Agency (EPA) has funded a pilot project to assist small and medium-size manufacturers who want to minimize their generation of waste but who lack the expertise to do so. In an effort to assist these manufacturers Waste Minimization Assessment Centers (WMACs) were established at selected universities and procedures were adapted from the EPA Waste Minimization Opportunity Assessment Manual (EPA/625/7-88/003, July 1988). That document has been superseded by the Facility Pollution Prevention Guide (EPA/600/R-92/088). The WMAC team at the University of Tennessee performed an assessment at a plant that fabricates and finishes metal components that are assembled into several types of locking devices. Raw materials are machined and then shipped offsite for heat-treating, stored until needed, or buffed and cleaned. Then, all parts other than those made of stainless steel are electroplated, electrostatically powder coated, or lacquer coated. The various component parts are then assembled into the locking devices. The assessment team's report, detailing findings and recommendations, indicated that the vapor degreasers generate a significant amount of waste and that vapor degreasing could be replaced with an aqueous cleaning system for intermediate cleaning.

This Research Brief was developed by the principal investigators and EPA's National Risk Management Research Laboratory, Cincinnati, $\mathrm{OH}$, to announce key findings of an ongoing research project that is fully documented in a separate report of the same title available from University City Science Center.

\footnotetext{
- University of Tennessee, Department of Engineering Science and Mechanics

* University City Science Center, Philadelphia, PA
} waste at its source. tion.

\section{Introduction}

\section{OCT 241995}

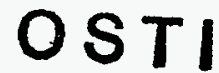

The amount of waste generated by industrial plants has become an increasingly costly problem for manufacturers and an additional stress on the environment. One solution to the problem of waste generation is to reduce or eliminate the

University City Science Center (Philadelphia, PA) has begun a pilot project to assist small and medium-size manufacturers who want to minimize their generation of waste but who lack the in-house expertise to do so. Under agreement with EPA's National Risk Management Research Laboratory, the Science Center has established three WMACs. This assessment was done by engineering faculty and students at the University of Tennessee WMAC. The assessment teams have considerable direct experience with process operations in manufacturing plants and also have the knowledge and skills needed to minimize waste generation.

The pollution prevention assessments are done for small and medium-size manufacturers at no out-of-pocket cost to the client. To qualify for the assessment, each client must fall within Standard Industrial Classification Code 20-39, have gross annual sales not exceeding $\$ 75$ million, employ no more than 500 persons, and lack in-house expertise in pollution preven-

The potential benefits of the pilot project include minimization of the amount of waste generated by manufacturers, and reduction of waste treatment and disposal costs for participating plants. In addition, the project provides valuable experience for graduate and undergraduate students who participate in the program, and a cleaner environment without more regulations and higher costs for manufacturers.

\section{DISTAIBUTION OF THIS DOCUMENT IS UNLMATED}

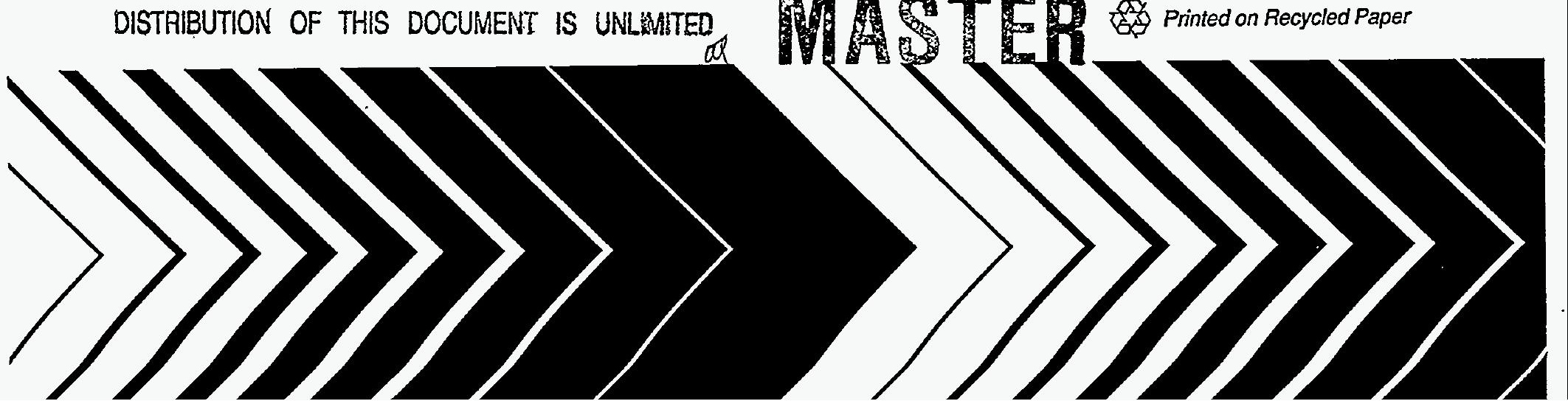




\section{Methodology of Assessments}

The pollution prevention opportunity assessments require several site visits to each client served. In general, the WMACs follow the procedures outlined in the EPA Waste Minimization Opportunity Assessment Manual (EPAV625/7-88/003, July 1988). The WMAC staff locate the sources of waste in the plant and identify the current disposal or treatment methods and their associated costs. They then identify and analyze a variety of ways to reduce or eliminate the waste. Specific measures to achieve that goal are recommended and the essential supporting technological and economic information is developed. Finally, a confidential report that details the WMAC's findings and recommendations (including cost savings, implementation costs, and payback times) is prepared for each client.

\section{Plant Background}

This plant fabricates and finishes metal components which are assembled into several types of locking devices. Approximately one million units are produced annually by this plant during $5,880 \mathrm{hr} / \mathrm{yr}$ of operation.

\section{Manufacturing Process}

The operations used by this plant are described below.

\section{Component Parts Manufacturing}

The major raw materials used by the plant include zinc die castings and carbon and stainless steel, brass, and bronze in bars, coils, and rods. Raw materials are moved by forklift to the metal fabrication area where cutting, bending and shaping, drilling, milling, screwing, and tapping operations are performed.

Prior to subsequent finishing operations, residual machining lubricant is removed from the parts in one of two vapor degreasers utilizing trichloroethylene. Contaminated trichloroethylene is distilled onsite and reused.

After cleaning, the parts are processed in one of three ways Some of the steel parts are shipped offsite for heat treatment and then returned to the plant for further processing. A portion of the parts is placed into storage until needed for production at a later time. The majority of parts which become external locking device parts are buffed to improve their appearance, either by hand or in an automatic system. Parts that have been buffed are cleaned in a third vapor degreaser.

All parts except those made of stainless steel require a surface coating. Most of the parts require one or more layers of electroplating. The second major type of coating used is electrostatic coating, and the third type is lacquer application to prevent tarnishing.

After the necessary coating process is complete, the component parts are transported to the assembly area where the different locking devices are assembled and packaged.

\section{Electroplating Operations}

Because the electroplating operations generate a significant amount of waste they are described in more detail in this section.

Parts that are to be plated that have not been buffed are first placed into vibratory devices for removal of any surface irregularities. Those parts are then conveyed through a small vapor degreaser, washed in a series of two wash tanks, and rinsed.
Three different plating lines are used by the plant. A small quantity of special parts is plated in a small-scale hand-plating line. Typical plating runs include chrome-or black chrome-, bronze-, or brass-plating and hot water rinsing between each plating stage and at conclusion.

Smaller parts that are used on the majority of the locking devices are placed into barrels for plating in the barrel-plating line. For corrosion protection, typical plating includes copper striking and plating, dull and bright nickel plating, and chrome plating with hot water rinsing between each stage and at a final rinsing station.

Larger parts are placed onto racks and mechanically carried through the rack-plating line. These parts are plated with zinc, copper strike and plating, bronze, brass, nickel, and chrome for decoration.

After parts have been processed through the appropriate plating line, they are removed from the conveying devices, allowed to air dry, and carried to the assembly area.

An abbreviated process flow diagram for this plant is shown in Figure 1.

\section{Existing Waste Management Practices}

This plant already has implemented the following techniques to manage and minimize its wastes.

- A filter press and a drying oven are used to reduce the volume of hazardous wastewater treatment sludge shipped offsite.

- Each vapor degreaser is served by a distillation unit for the recycle and reuse of spent trichloroethylene.

- Counterflow rinsing is used in the plating operations.

- Flow restrictors have been installed on the water removal lines of the electroplating rinse tanks to reduce the volume of wastewater generated.

- A compactor is used to reduce the volume of nonhazardous solid waste shipped to the municipal landfill.

- Water-based coolant and cutting oil is removed from metal shavings using a centrifuge and returned to the metal fabrication units.

- Scrap metal shavings are recycled offsite.

- Canvas coverings have been installed over the openings of the vapor degreaser units to reduce evaporative losses of solvent.

\section{Pollution Prevention Opportunities}

The type of waste currently generated by the plant, the source of the waste, the waste management method, the quantity of the waste, and the annual treatment and disposal cost for each waste stream identified are given in Table 1.

Table 2 shows the opportunities for pollution prevention that the WMAC team recommended for the plant. The opportunity, the type of waste, the possible waste reduction and associated savings, and the implementation cost along with the simple payback time are given in the table. The quantities of waste 


\section{DISCLAIMER}

This report was prepared as an account of work sponsored by an agency of the United States Government. Neither the United States Government nor any agency thereof, nor any of their employees, make any warranty, express or implied, or assumes any legal liability or responsibility for the accuracy, completeness, or usefulness of any information, apparatus, product, or process disclosed, or represents that its use would not infringe privately owned rights. Reference herein to any specific commercial product, process, or service by trade name, trademark, manufacturer, or otherwise does not necessarily constitute or imply its endorsement, recommendation, or favoring by the United States Government or any agency thereof. The views and opinions of authors expressed herein do not necessarily state or reflect those of the United States Government or any agency thereof. 


\section{DISCLAIMER}

Portions of this document may be illegible in electronic image products. Images are produced from the best available original document. 
currently generated by the plant and possible waste reduction depend on the production level of the plant. All values should be considered in that context.

It should be noted that the economic savings of the opportunity, in most cases, results from the reduction in raw material and costs associated with waste treatment and disposal. Other savings not quantifiable by this study include a wide variety of possible future costs related to changing emissions standards, liability, and employee health. It also should be noted that the savings given for each opportunity reflect that pollution prevention opportunity alone and do not reflect duplication of savings that may result when the opportunities are implemented in a package.

\section{Additional Recommendations}

In addition to the opportunities recommended and analyzed by the WMAC team, two other measures were considered. These measures were not analyzed completely because of a lack of sufficient information for analysis or an anticipated lengthy payback period. Since these approaches to pollution prevention may, however, increase in attractiveness with changing conditions in the plant, they were brought to the plant's attention for future consideration.

- Install rinse devices above each plating and wash tank to spray water onto each part as it is removed from the tank in order to return plating and wash solutions to their tanks before drag-out occurs. In order to compensate for the increased amount of water being added to the tanks, it is proposed that fan units be used to blow air across the surface of each tank to promote evaporation of excess water. Dragout boards should be installed on each tank.

- Implement electrostatic application of lacquer coating to component surfaces to reduce the current level of overspray and raw material purchases.

This research brief summarizes a part of the work done under Cooperation Agreement No. CR-814903 by the University City Science Center under the sponsorship of the U.S. Environmental Protection Agency. The EPA Project Officer was Emma Lou George. 


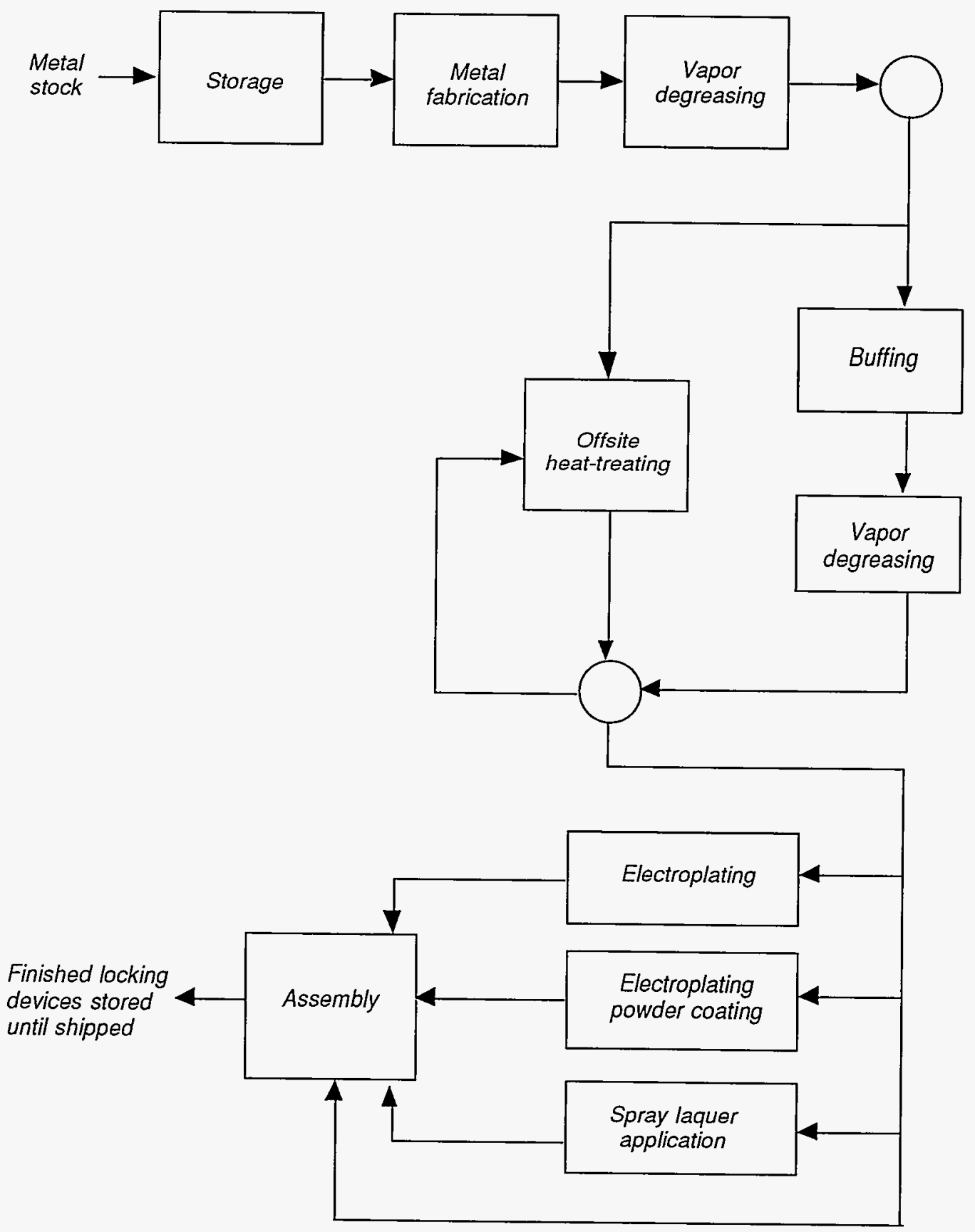

Figure 1. Abbreviated process flow diagram for locking device fabrication. 
Table 1. Summary of Current Waste Generation

\begin{tabular}{|c|c|c|c|c|}
\hline Waste Stream Generated & Source of Waste & Waste Management Method & $\begin{array}{l}\text { Annual Quantity } \\
\text { Generated (lb/yr) }\end{array}$ & $\begin{array}{c}\text { Annual Waste } \\
\text { Management Cost }{ }^{1}\end{array}$ \\
\hline Cardboard packaging & Aaw material shipments & Compacted; shipped to municipal landfill & 218,400 & $\$ 30,740$ \\
\hline Wooden pallets & Aaw material shipments & Compacted; shipped to municipal landfill & 46,800 & 6,590 \\
\hline Miscellaneous solid waste & Raw material shipments, buffing, electrostatic coating & Compacted; shipped to municipal landfill & 47,200 & 6,640 \\
\hline Brass shavings & Machining & Lubricant removed; sold to recycler & 390,200 & $\begin{array}{l}-314,990 \\
\text { (net revenue received) }\end{array}$ \\
\hline Steel shavings & Machining & Lubricant removed; sold to recycler & $1,069,700$ & $\begin{array}{l}-11,210 \\
\text { (net revenue received) }\end{array}$ \\
\hline Mixed metal shavings & Machining & Lubricant removed; sold to recycler & 247,370 & $\begin{array}{l}-48,020 \\
\text { (net revenue received) }\end{array}$ \\
\hline Spent trichloroethylene & Annual draining of vapor degreasers & Shipped offsite for disposal as hazardous waste & 28,700 & 41,590 \\
\hline Trichloroethylene still bottoms & Onsite distillation units for trichloroethylene reuse & Shipped offsite for disposal as hazardous waste & 3,000 & 11,590 \\
\hline Evaporated trichloroethylene & Vapor degreasers & Evaporates to plant air & 143,500 & 73,540 \\
\hline Cooling water & Vapor degreasers & Sewered & $140,000,000$ & 26,750 \\
\hline Corrosive solids & Lacquer removal tanks for defectively coated parts & Shipped offsite for disposal as hazardous waste & 5,010 & 17,250 \\
\hline Waste lacquer thinner & Lacquer application error & Shipped offsite for disposal as hazardous wasto & 1,960 & 10,470 \\
\hline Wastewater & Electroplating & $\begin{array}{l}\text { Treated in onsite wastewater treatment plant } \\
\text { piped to surface waters under NPDES permit }\end{array}$ & $140,000,000$ & 19,310 \\
\hline Wastewater treatment sludge & Onsite wastewater treatment plant & Shipped offsite for disposal as hazardous waste & 51,040 & 57,900 \\
\hline
\end{tabular}

${ }_{1}$ includes wasto treatment, disposal, and handling costs, and applicable raw material costs. 
Table 2. Summary of Recommended Pollution Prevention Opportunities

\begin{tabular}{|c|c|c|c|c|c|c|}
\hline \multirow[b]{2}{*}{ Pollution Prevention Opportunity } & \multirow[b]{2}{*}{ Waste Reduced } & \multicolumn{2}{|c|}{ Annual Waste Reduction } & \multirow{2}{*}{$\begin{array}{c}\text { Net Annual } \\
\text { Savings }\end{array}$} & \multirow{2}{*}{$\begin{array}{c}\text { Implementation } \\
\text { Cost }\end{array}$} & \multirow{2}{*}{$\begin{array}{c}\text { Simple } \\
\text { Payback (yr) }\end{array}$} \\
\hline & & Quantity (Ib/yr) & Per cent & & & \\
\hline \multirow{3}{*}{$\begin{array}{l}\text { Discontinue the use of the primary vapor } \\
\text { degreasing unit for intermediate cleaning } \\
\text { during machining operations. Install an } \\
\text { aqueous cleaning solution system to re- } \\
\text { move lubricant residues and then dry the } \\
\text { parts with forced-air blowers. Secondary } \\
\text { degreasing units should be used for the } \\
\text { final removal of surface contaminants } \\
\text { prior to electroplating operations. A non- } \\
\text { hazardous water/detergent waste stream } \\
\text { will be generated if this opportunity is im- } \\
\text { plemented. }\end{array}$} & Spent trichloroethylene & 8,610 & 30 & $\$ 28,680$ & $\$ 56,700$ & 2.0 \\
\hline & Trichloroethylene still bottoms & 900 & 30 & & & \\
\hline & Evaporated trichloroethylene & 43,050 & 30 & & & \\
\hline $\begin{array}{l}\text { Re-train the vapor degreaser operators to } \\
\text { lower the existing canvas covers over the } \\
\text { entrance and exit openings of each de- } \\
\text { greaser unit in order to decrease trichloro- } \\
\text { ethylene evaporative losses. Currently, the } \\
\text { canvas coverings are not routinely used. }\end{array}$ & Evaporated irichloroethylene & 71,750 & 50 & 32,290 & $o$ & 0 \\
\hline \multirow{3}{*}{$\begin{array}{l}\text { Institute a recycling program to segregate } \\
\text { cardboard and wood material from other } \\
\text { solid wastes for cardboard recycling and } \\
\text { sale of wood for domestic heating. Imple- } \\
\text { mentation of this measure will lead to } \\
\text { revenue generation through the sale of } \\
\text { waste material and reduced landfill costs. } \\
\text { No waste reduction will result from this } \\
\text { measure. }\end{array}$} & Cardboard packaging & 一 & - & $15,785^{1}$ & 0 & 0 \\
\hline & Wooden pallets & 一- & - & & & \\
\hline & Miscellaneous solid waste & 一- & - & & & \\
\hline $\begin{array}{l}\text { Install a cooling tower in order to recycle } \\
\text { the cooling water used to reduce evapor. } \\
\text { ative losses from the vapor degreasers. } \\
\text { Currently, water is delivered to the units } \\
\text { continuously and carried directly to the } \\
\text { POTW. }\end{array}$ & Cooling water & $133,000,000$ & 95 & $22,170^{1}$ & 59,000 & 2.7 \\
\hline
\end{tabular}

${ }^{1}$ Total annual savings have been reduced by an annual operating cost required for implementation. 